\title{
RELATIVE PERFORMANCE OF SUGAR BEET VARIETIES UNDER THREE PLANT DENSITIES IN NEWLY RECLAIMED SOIL
}

\author{
SHALABY, N.M.E., A.M.H. OSMAN AND A.H.S.A. AL-LABBODY \\ Sugar Crops Res. Inst., ARC, Giza, Egypt.
}

(Manuscript received 15 September 2010 )

\begin{abstract}
Two field experiments were carried out during 2008/2009 and 2009/2010 seasons at Kom Oshem, Fayoum Governorate to study the effect of three hill spacing, 15, 20 and $25 \mathrm{~cm}$ and three sugar beet varieties Pleno, Sultan and Kawemira as well as their interaction on sugar beet productivity. Sugar beet varieties were planted on $1^{\text {st }}$ November in both seasons. The obtained results revealed that: increasing plant spacing from 15 to $25 \mathrm{~cm}$ increased significantly root length and diameter, fresh weight, sucrose $\%$, root and sugar yields/fed. Impurities\%, i.e. ( $\mathrm{N}, \mathrm{Na}$ and $\mathrm{K}$ ) were decreased significantly in both seasons. Sugar beet varieties gave increased significantly root length, diameter, fresh weight, sucrose $\%$, root and sugar yields/fed. Decreased significantly impurities\% in both seasons. The interaction was significant in both seasons for root length, fresh weight and root yields/fed. In general, sowing sugar beet at $25 \mathrm{~cm}$ using Kawemira variety was the best treatment for maximizing productivity under the environmental conditions of this study.
\end{abstract}

\section{INTRODUCTION}

Sugar beet ranks the second sugar crop after sugar cane crop in the world as it provides about $40 \%$ of the worlds sugar production. Egyptian Government imports about 1.10 milion ton of sugar, every year to face the rapid increase of population. Sugar beet plays a prominent role in sugar production, about $37.27 \%$ of the local sugar production, which amounted to 1.61 million ton, is produced from sugar beet, which is considered the second sugar crop after sugar cane. (CCSC, 2010). The optimum plant densities in sugar beet is very necessary to have high root yield with good quality. Abou El-Magd et al (2003) in Egypt, found that delaying harvesting date up to 210 days after sowing significantly decreased nitrogen, sodium and potassium $\%$ in juice roots. El-Bakary (2006) and Ismail and Allam (2007) showed that plant densities significantly affected root length and diameter, fresh weight/plants, as well as sodium $\%$ and sucrose $\%$ in both seasons in addition to sugar yield in the $2^{\text {nd }}$ season. They added that sowing sugar beet at 28000 and 42000 plants/fed gave the highest yield of root and sugar (tons/fed) and quality traits, respectively. Nafei et al (2010) used three plant densities 28000 (50 cm between rows $\times 30 \mathrm{~cm}$ between hills), 33600 (50 cm between rows $\times 25 \mathrm{~cm}$ between hills) and 42000 (50 cm between rows $x 20 \mathrm{~cm}$ between hills). They reported that increasing plant population from 28000 to 
42000 plants/fed caused a significant response in root length, diameter, fresh weight/plants, sucrose $\%$, total soluble solids, phosphorus $\%$ in roots as well as top, root and sugar yield (ton/fed) in both seasons.

All sugar beet genotypes cultivated in Egypt are imported from foreign countries, so, it is preferable to evaluate them under Egyptian conditions especially under newly reclaimed soil to select the best suited ones. Osman et al (2003) found significant differences among the studied sugar beet varieties Gloria, Toro and Pamela in root length, diameter, fresh weight, root and sugar yield (ton/fed), as well as sucrose and purity $\%$ whereas Toro variety produced significantly higher TSS\% compared with Gloria and Pamela varieties. Azzazy (2004), Abd El-Aal and Amal (2005) showed that the examined sugar beet varieties varied significantly for root fresh weight/plant, root and sugar yields/fed, while root length and diameter as well as sucrose and purity\% did not differ significantly. Sugar beet variety KWS-9422 gave the highest root and sugar yields/fed. Aly (2006), El-Bakary (2006) and Ismail et al (2006) found that genotypes differed significantly in growth, i.e. root length, diameter and root fresh weight as well as top, root and sugar yields/fed. Also, impurities\% $\mathrm{Na}$, $\mathrm{K}$ and $\mathrm{N} \%$ in sugar beet roots and quality sucrose and purity\% in both seasons, except impurities $\mathrm{Na}$ and $\mathrm{K} \%$ in both seasons. Farida and Gazella genotypes gave the highest values, while, Samba and LPII contained the highest impurities\%. The aim of this study was to select the best treatment to obtained the highest yield and quality by planting sugar beet varieties at different hill spacing.

\section{MATERIALS AND METHODS}

Two field experiments were carried out during 2008/2009 and 2009/2010 seasons at Kom Oshem, Fayoum Governorate to study the effect of three hill spacings, 15, 20 and $25 \mathrm{~cm}$ and three sugar beet varieties Pleno, Sultan and Kawemira as well and their interaction on sugar beet productivity. Sugar beet varieties were planted on $1^{\text {st }}$ November in both seasons. The experimental design was a split-plot design with four replications, three hill spacings were allocated in the main plots and the three sugar beet varieties were in the sub-plots. Nitrogen fertilizer level at the rate of $100 \mathrm{~kg}$ $\mathrm{N} /$ fed in the form of ammonium nitrate (33.5\%) was applied in four equal portions, the first was applied after thinning and the other was applied at 2-week interval after the first application. Phosphorus fertilizer level at the rate of $45 \mathrm{~kg} \mathrm{P}_{2} \mathrm{O}_{5} / \mathrm{fed}$ in the form of Calcium super phosphate $\left(15.5 \% \mathrm{P}_{2} \mathrm{O}_{5}\right)$ was added during land preparation. Potassium fertilizer rate of $36 \mathrm{~kg} \mathrm{~K} 2 \mathrm{O} / \mathrm{fed}$ in the form of potassium sulfate $\left(48 \% \mathrm{~K}_{2} \mathrm{O}\right)$ was applied in four equal doses with nitrogen fertilizer. Some physical and chemical analysis of the experimental site according to Page (1982) are shown in Table 1. 
Table 1. Some physical and chemical analysis of the experimental site.

\begin{tabular}{|c|c|c|c|c|c|c|c|c|c|c|c|}
\hline \multicolumn{4}{|c|}{ Particle size } & \multicolumn{2}{|c|}{ Soil textural } & \multirow{2}{*}{\multicolumn{2}{|c|}{$* *$ E.C. ds/m }} & \multirow{2}{*}{$\begin{array}{c}\text { Soil pH* } \\
(1: 2.5)\end{array}$} & \multirow{2}{*}{\multicolumn{2}{|c|}{$\begin{array}{c}\text { Organic matter } \\
\% \\
\end{array}$}} & \multirow{2}{*}{$\mathrm{CaCO}_{3} \%$} \\
\hline Sand\% & Silt \% & & \% $\%$ & \multirow{2}{*}{\multicolumn{2}{|c|}{ Sand silty loam }} & & & & & & \\
\hline 25.3 & 59.7 & & 5.0 & & & & .90 & 7.2 & & 18 & 3.08 \\
\hline \multicolumn{4}{|c|}{ Soluble Cations (meq/L) } & \multicolumn{5}{|c|}{ Soluble anions(meq/L) } & \multicolumn{3}{|c|}{ Nutrient contents (ppm) } \\
\hline $\mathrm{Ca}^{++}$ & $\mathrm{Mg}^{++}$ & $\mathrm{Na}^{+}$ & $\mathrm{K}^{+}$ & $\mathrm{CO}_{3}{ }^{-}$ & & & $\mathrm{Cl}^{-}$ & $\mathrm{SO}_{4}^{--}$ & $\mathrm{N}$ & $P$ & K \\
\hline 2.03 & 3.02 & 4.24 & 0.15 & 0.15 & & & 6.02 & 3.27 & 17.9 & 20.2 & 56.3 \\
\hline
\end{tabular}

$* \mathrm{pH}$ was measured in a soil - water suspension (1:2.5).

** EC $=$ Electrical conductivity was measured in a soil - water extract (1:5).

Other agricultural practices required for growing sugar beet were carried out as usuall. Plants were harvested after 180 days from sowing. The preceeding crop was Maize in both seasons.

\section{Recorded data}

At harvest, ten guarded sugar beet plants were taken at random from each plot to determine the following traits:

1. Root length $(\mathrm{cm})$.

2. Root diameter $(\mathrm{cm})$.

3. Root fresh weight ( $\mathrm{g} / \mathrm{plants})$.

4. Root yield (ton/fed) roots and tops were separated and each was weighted to determine root yields/fed.

5. Sugar yield (ton/fed) was calculated by multiplying root yield by sucrose $\%$.

6. Sucrose\% was estimated polarimetrically on a lead acetate extract of fresh macerated roots according to Le-Docte (1927).

7. Macroelements\% ( $\mathrm{N}, \mathrm{Na}$ and $\mathrm{K}$ ) were determined according to the method described by AOAC (2005).

Data were statistically analyzed according to Snedecor and Cochran (1981).

\section{RESULTS AND DISCUSSION}

\section{Hill spacing effects}

Effect of hill spacing on root growth, quality, macroelements $\%$ and yields at harvest.

\section{I.1. Effects on growth traits and sucrose\%}

The obtained results in Table 2 show that increasing distance within plants increases significantly root performance in term of root length, root diameter and fresh weight/plant, sucrose $\%$, root and sugar yields/fed) and impurities\% i.e. nitrogen $(\mathrm{N})$, sodium $(\mathrm{Na})$ and potassium $(\mathrm{K})$ in both seasons. The highest mean values of root 
length, diameter, fresh weight and sucrose $\%$ as affected by $25 \mathrm{~cm}$ plant spacing in both seasons are presented in Table 2.

The increase of root length, diameter, fresh weight/plant and sucrose $\%$ could be attributed to a possible increase in the proportion of invisible solar radiation caused by mutual shading. (Chang 1974). These results are in agreement with those reported by El-Bakary (2006) and Nafei et al (2010).

Table 2. Effect of hill spacing on growth, quality traits and yields at harvest.

\begin{tabular}{|c|c|c|c|c|c|c|c|c|c|}
\hline \multicolumn{10}{|c|}{$2008 / 2009$ season } \\
\hline Traits & \multicolumn{3}{|c|}{ Root growth traits } & \multirow{2}{*}{$\begin{array}{c}\text { quality } \\
\% \\
\text { Suc. }\end{array}$} & \multicolumn{2}{|c|}{ Yields (ton/fed) } & \multicolumn{3}{|c|}{ Macroelements\% } \\
\hline Hill space & RL & $\mathrm{RD}$ & RFW & & RY & SY & $\mathrm{N}$ & $\mathrm{Na}$ & K \\
\hline $15 \mathrm{~cm}$ & 28.50 & 11.00 & 892.67 & 13.33 & 26.88 & 3.5 & 1.43 & 2.0 & 5.87 \\
\hline $20 \mathrm{~cm}$ & 29.44 & 12.00 & 1040.3 & 15.00 & 28.38 & 4.2 & 1.18 & 1.9 & 5.43 \\
\hline $25 \mathrm{~cm}$ & 31.70 & 13.00 & 1132.3 & 16.50 & 30.33 & 4.6 & 1.12 & 1.8 & 5.15 \\
\hline LSD at $5 \%$ & 1.75 & 1.10 & 75.12 & 1.12 & 1.85 & 0.85 & 0.13 & 0.11 & 0.31 \\
\hline \multicolumn{10}{|c|}{$2009 / 2010$ season } \\
\hline $15 \mathrm{~cm}$ & 23.67 & 12.00 & 861.67 & 15.00 & 25.98 & 4.1 & 1.75 & 2.5 & 6.13 \\
\hline $20 \mathrm{~cm}$ & 26.00 & 13.19 & 1021.7 & 16.00 & 28.65 & 4.6 & 1.63 & 2.0 & 5.50 \\
\hline $25 \mathrm{~cm}$ & 27.67 & 13.88 & 1189.3 & 17.00 & 30.01 & 5.3 & 1.46 & 1.9 & 5.03 \\
\hline LSD at $5 \%$ & 0.65 & 1.15 & 55.25 & 0.47 & 1.50 & 0.62 & 0.09 & 0.10 & 0.13 \\
\hline
\end{tabular}

$\mathrm{RL}=$ Root length $(\mathrm{cm}), \mathrm{RD}=$ Root diameter $(\mathrm{cm}), \mathrm{RFW}=$ Root fresh weight $(\mathrm{g} /$ plant $)$, Suc. $=$ Sucrose\%, RY $=$ Root yield (ton/fed), SY = Sugar yield (ton/fed), Macroelements, i.e. $\mathrm{N}=$ Nitrogen $\%, \mathrm{Na}=$ Sodium $\%$ and $\mathrm{K}=$ Potassium $\%$.

\section{I.2. Effect on yields (ton/fed)}

Results in Table 2 cleared that root and sugar yields/fed significantly increased as hill spacing increased in both seasons. Hill spacing of $25 \mathrm{~cm}$ gave the highest values for root and sugar yields/fed, in first and second seasons (Table 2). The increase in root yields/fed being strongly related to root performance, i.e. root length, diameter and fresh weight $\mathrm{g} / \mathrm{plant}$. The increase in sugar yield may be due to $25 \mathrm{~cm}$ hill space was superior, also, in quality traits, i.e. sucrose $\%$ as well as root yield. The increase of root yields/fed, may be attributed to the less inter-plant competition for light and nutrients as well as mutual shading in case of higher hill spacing $(25 \mathrm{~cm})$, 
(Chang 1974). These results are similar to those revealed by El-Bakary (2006) and Nafei et al (2010).

\section{I.3. Effects on macoelements\%}

Results presented in Table 2 show that increasing hill spacing within beet plant gradually reduced macroelements $\%$ in both seasons. These results agree with those reported by Abou El-Magd et al (2003), El-Bakary (2006) and Nafei et al. (2010).

\section{Varietal differences}

\section{1. Effects on growth traits and sucrose\%}

Data in Table 3 show the effect of varieties on root length and diameter, fresh weight as well as sucrose\% were significantly affected in both seasons. Kawemira variety exhibited the highest values of root length, diameter, fresh weight and sucrose $\%$ in both seasons. These differences could be attributed to the genetic structure of the evaluated sugar beet varieties. These results were similar to those obtained by Aly (2006), El-Bakary (2006) and Ismail et al (2006).

Table 3. Effect of varietal differences on growth, quality traits and yields at harvest.

\begin{tabular}{|c|c|c|c|c|c|c|c|c|c|}
\hline \multicolumn{10}{|c|}{$2008 / 2009$ season } \\
\hline Traits & \multicolumn{3}{|c|}{ Root growth traits } & \multirow{2}{*}{$\begin{array}{c}\text { quality } \\
\% \\
\text { Suc. }\end{array}$} & \multicolumn{2}{|c|}{ Yields (ton/fed) } & \multicolumn{3}{|c|}{ Macroelements\% } \\
\hline Varieties & RL & RD & RFW & & RY & SY & $\mathrm{N}$ & $\mathrm{Na}$ & $\mathrm{K}$ \\
\hline Pleno & 28.22 & 11.00 & 915.3 & 13.83 & 26.66 & 3.50 & 1.38 & 1.9 & 5.77 \\
\hline Sultan & 29.39 & 12.00 & 1029.3 & 15.17 & 28.87 & 3.90 & 1.24 & 1.8 & 5.57 \\
\hline Kawemira & 32.03 & 13.00 & 1120.7 & 15.83 & 30.07 & 4.48 & 1.10 & 1.7 & 5.12 \\
\hline LSD at $5 \%$ & 1.55 & 0.90 & 45.20 & 0.85 & 0.95 & 0.35 & 0.10 & 0.09 & 0.12 \\
\hline \multicolumn{10}{|c|}{$2009 / 2010$ season } \\
\hline Pleno & 23.00 & 11.87 & 926.0 & 15.00 & 26.52 & 4.10 & 1.82 & 2.2 & 6.08 \\
\hline Sultan & 24.00 & 12.88 & 987.3 & 16.00 & 27.83 & 4.60 & 1.65 & 2.0 & 5.58 \\
\hline Kawemira & 30.33 & 14.33 & 1159.3 & 17.00 & 30.28 & 5.30 & 1.37 & 1.9 & 5.00 \\
\hline LSD at $5 \%$ & 0.35 & 0.75 & 25.15 & 0.27 & 0.75 & 0.21 & 0.05 & 0.04 & 0.08 \\
\hline
\end{tabular}

$\mathrm{RL}=$ Root length $(\mathrm{cm}), \mathrm{RD}=$ Root diameter $(\mathrm{cm}), \mathrm{RFW}=$ Root fresh weight $(\mathrm{g} /$ plant $)$, Suc. $=$ Sucrose $\%, \mathrm{RY}=$ Root yield (ton/fed), SY = Sugar yield (ton/fed), Macroelements, i.e. $\mathrm{N}=$ Nitrogen $\%, \mathrm{Na}=$ Sodium $\%$ and $\mathrm{K}=$ Potassium $\%$. 


\section{II.2. Effects on yields (ton/fed)}

Results cleared in Table 3 show that the effect of varieties showed significant differences in root and sugar yields/fed in both seasons. Kawemira variety ranked first and gave the highest mean values of root and sugar yields/fed followed by Sultan and Pleno varieties. These differences could be attributed to the genetic structure of the evaluated sugar beet varieties. The increase in root yield was strongly related to root performance, i.e. root length, diameter and fresh weight. The increase in sugar yield may be due to that Kawemira variety was superior, also, in quality traits, i.e. sucrose\% as well as root yield. Similar results were obtained by Aly (2006), El-Bakary (2006) and Ismail et al (2006).

\section{III.3. Effects on macroelements\%}

Results in Table 3 illustrated that varieties reduced significantly in $\mathrm{N}$. Na and $\mathrm{K} \%$ in both seasons. Kawemira variety gave the lowest mean values for $\mathrm{N}, \mathrm{Na}$ and $\mathrm{K} \%$ in both seasons, compared with the other two varieties. Similar results were recorded by Abou El-Magd et al (2003), Aly (2006), El-Bakary (2006) and Ismail et al(2006).

\section{Interaction effects}

\section{1. Effects on growth traits}

Results illustrated in Table 4 show that the interaction effect between hill spacing and varieties on root length and root fresh weight was significant in both seasons. Kawemira variety $\mathrm{x}$ hill spacing of $25 \mathrm{~cm}$ exhibited the highest root length and fresh weight. While, the interaction effect on root diameter was significant in the $2^{\text {nd }}$ season only.

\section{III.2. Effects on yields (ton/fed)}

Results in Table 4 indicate that a significant effect of the interaction between hill spacing and varieties on root yield in both seasons. Sowing Kawemira variety $\mathrm{x}$ hill spacing $25 \mathrm{~cm}$ gave the highest root yield. Sugar yield significantly affected by the interaction in the $1^{\text {st }}$ season only. The interaction between hill spacing $x$ Kawemira variety gave the highest sugar yield (5.64 ton/fed).

\section{III.3. Effects on macroelements\%}

The tabulated results in Table 4 pointed out that the interaction between hill spacing $x$ Kawemira variety on nitrogen and potassium $\%$ were reduced significantly in both seasons. Sowing Kawemira variety $x$ hill spacing $25 \mathrm{~cm}$ gave the lowest mean values for $\mathrm{N}$ and $\mathrm{K}$ in both seasons. 
Table 4. Effect of interaction between hill spacings $x$ varieties on roots growth and yields at harvest.

\begin{tabular}{|c|c|c|c|c|c|c|}
\hline \multicolumn{7}{|c|}{$2008 / 2009$ season } \\
\hline Traits & \multicolumn{2}{|c|}{ Root growth traits } & \multicolumn{2}{|c|}{ Yields (ton/fed) } & \multicolumn{2}{|c|}{ Macroelements $\%$} \\
\hline Interactions & RL & RFW & RY & SY & $\mathrm{N}$ & K \\
\hline $15 \times$ v1 & 27.00 & 823 & 25.65 & 3.21 & 1.60 & 6.10 \\
\hline $20 \times v 1$ & 28.00 & 918 & 26.00 & 3.64 & 1.35 & 5.75 \\
\hline $25 \times v 1$ & 29.67 & 1005 & 28.33 & 4.25 & 1.20 & 5.45 \\
\hline $15 \times$ v2 & 28.50 & 905 & 27.10 & 3.66 & 1.43 & 6.00 \\
\hline $20 \times$ v2 & 29.00 & 1050 & 29.15 & 4.37 & 1.13 & 5.55 \\
\hline $25 \times v 2$ & 30.67 & 1133 & 30.35 & 5.16 & 1.15 & 5.15 \\
\hline $15 \times v 3$ & 30.00 & 950 & 27.90 & 3.91 & 1.25 & 5.50 \\
\hline $20 \times$ v3 & 31.33 & 1153 & 30.00 & 4.80 & 1.05 & 5.00 \\
\hline $25 \times v 3$ & 34.75 & 1259 & 32.30 & 5.64 & 1.00 & 4.85 \\
\hline LSD at $5 \%$ & 1.50 & 0.01 & 0.20 & 0.11 & 0.14 & 0.20 \\
\hline \multicolumn{7}{|c|}{$2009 / 2010$ season } \\
\hline Traits & \multicolumn{3}{|c|}{ Root growth traits } & $\begin{array}{c}\text { Yield } \\
\text { (ton/fed) }\end{array}$ & \multicolumn{2}{|c|}{ Macroelements\% } \\
\hline Interactions & RL & RD & RFW & RY & $\mathrm{N}$ & K \\
\hline $15 \times v 1$ & 21.00 & 11.00 & 800 & 24.10 & 1.90 & 6.50 \\
\hline $20 \times v 1$ & 23.00 & 12.10 & 913 & 27.30 & 1.85 & 6.00 \\
\hline $25 \times v 1$ & 25.00 & 12.50 & 1065 & 28.15 & 1.70 & 5.75 \\
\hline $15 \times$ v2 & 22.00 & 12.00 & 835 & 25.33 & 1.80 & 6.10 \\
\hline $20 \times v 2$ & 24.00 & 13.15 & 957 & 28.50 & 1.65 & 5.50 \\
\hline $25 \times$ v2 & 26.00 & 13.50 & 1170 & 29.67 & 1.50 & 5.15 \\
\hline $15 \times v 3$ & 28.00 & 13.00 & 950 & 28.50 & 1.55 & 5.80 \\
\hline $20 \times$ v3 & 31.00 & 14.33 & 1195 & 30.14 & 1.40 & 5.00 \\
\hline $25 \times v 3$ & 32.00 & 15.65 & 1333 & 32.20 & 1.17 & 4.20 \\
\hline LSD at $5 \%$ & 2.00 & 0.60 & 10.01 & 0.42 & 0.25 & 0.17 \\
\hline
\end{tabular}

$\mathrm{RL}=$ Root length $(\mathrm{cm}), \mathrm{RD}=$ Root diameter $(\mathrm{cm}), \mathrm{RFW}=$ Root fresh weight $(\mathrm{g} /$ plant),

$\mathrm{RY}=$ Root yield (ton/fed), SY = Sugar yield (ton/fed), Macroelements, i.e. $\mathrm{N}=$ Nitrogen $\%$ and $\mathrm{K}=$ Potassium $\%$. 


\section{REFERENCES}

1. Abd El-Aal, A.M. and Z.A.M. Amal. 2005. Genotype x Environment interaction and stability analysis for yield and quality of some sugar beet genotypes. Annals of Agric Sc., Moshtohor, 43 (2): 527-544.

2. Abo-El Magd, B.M., M.F. Ebraheim and KH.A. Aboushady. 2003. Some chemical and technological characteristics by planting methods and different harvesting dates. J. Agric. Sci., Mansoura Univ., 28 (7): 5115-5128.

3. Aly, E.F. 2006. Effect of environmental conditions on productivity and quality of some sugar beet varieties. Ph. D. Thesis. Fac. of Agric. Benha Univ. Egypt.

4. Association of Official Agricultural Chemist. 1995. Official methods of analysis pupl. by the AOAC Box 540, Washington.

5. Azzazy, N.B. (2004). Yield and quality of some sugar beet varieties as affected by water quality and nitrogen fertilizer. Egypt. J. Agric. Res., 82 (4): 1733-1745.

6. CCSC. 2010. Sugar Crops Council. Annual Report, Ministry of Agriculture, Egypt. (In Arabic).

7. Chang, J.H. 1974. Reparation balance. Climate and Agriculture Aldine Publ. Company, Chicago, Illinois: 4-22.

8. El-Bakary, H.M.Y. 2006. Studies on yield and quality characters of some sugar beet varieties. M.Sc. Thesis Fac. of Agric Al-Azhar Univ. Egypt.

9. Ismail, A.M.A., A.H.S. Al-Labbody and N.M.S. Shalaby (2006). Variability and traits relationship in nine sugar beet varieties under three sowing dates. Egypt. J. Plant Breed. 10 (1): 387-406.

10. Ismail, A.M.A. and S.M. Allam. 2007. Yield and technological traits of sugar beet as affected by planting density, $\mathrm{P}$ and $\mathrm{K}$ fertilization. The $3^{\text {rd }}$ Conf. Sustain. Agric. Develop., Fac. Agric., Fayoum Univ., 12-14 Nov. 15-28.

11. Le-Docte, A. 1927. Commercial determination of sugar in the beet root using the sacks. Le-Docte Process. Int. Sug. J. 29: 488-492.

12. Nafei. A.I., A.M.H. Osman and Maha M. El.Zeny. 2010. Effect of plant densities and potassium fertilization rates on yield and quality of sugar beet crop in sandy reclaimed soils. J. of plant production. Mansoura Univ., 1 (2): 229-237.

13. Osman, A.M.H., G.S. El-Sayed, M.S.H. Osman and K.S. El-Sogheir. 2003. Soil application of some microelements with relation to yield and quality of sugar beet varieties. Annals of Agric. Sc., Moshtohor, 41 (3): 1071-1088.

14. Page, A.L. 1982. "Methods of Soil Analysis". Chemical and Microbiological Properties. $2^{\text {nd }}$ ed., Agron. 9, Am. Soc. Agron. Inc. Publ. Madison, Wis, USA.

15. Snedecor, G.W. and W.G. Cochran. 1981. Statistical Methods. $7^{\text {th }}$ Ed. Iowa State Univ. Press, Ames, Iowa, USA. 


\section{الاداء النسبى لبعض اصناف بنجر السكر وثثلاث كثافات نباتية تحت ظروف الاراضى حديثة الاستصلاح}

ناصر محمد السيد شلبى عادل محمود حسن عثمان اشرف حنفى سيد احمد اللبودى معهز بحوث المحاصيل السكرية- مركز البحوث الزراعية- جيزة- مصر

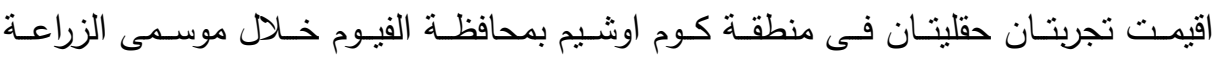

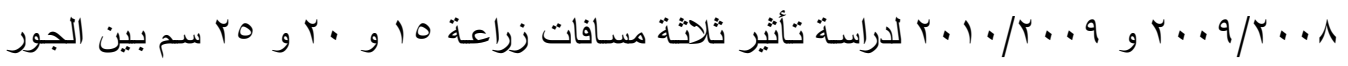
وثلاثة أصناف من بنجر السكر بلينو و سلطان وكاوميرا وتاثيرها على محصول بنجر السكر . وكان

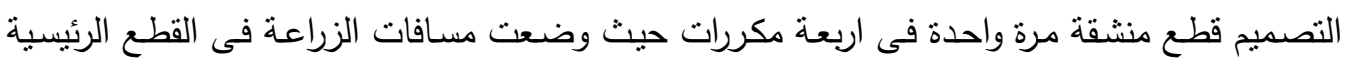
والاصناف فى القطع الثقية الاولى. أوضحت الننائج:

- نباين تاثير مسافات الزراعة والاصناف معنويا على كل الصفات فى كلا الموسميين وقد حققت المسافة OY سم بين الجور والصنف كاوميرا اعلى محصول وجودة واقل قيم للثوائب.

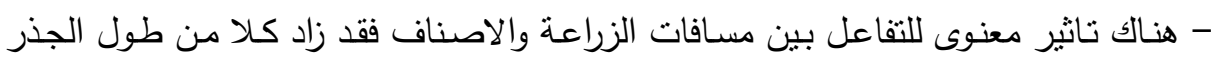
ووزن الجذر ومحصول الجذور وقلت النسبة المئوية للثوائب فى الجذور فى كلا الموسميين. بينما كانت معنوية فى الموسم الاول فقط لمحصول السكر ولقطر الجذر فى الموسم الثانى فقط.

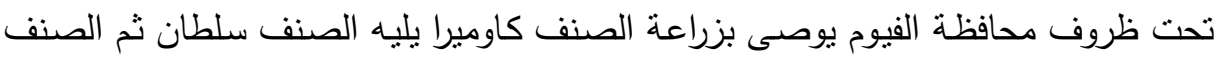
بلينو مع مسافة زراعة بين الجور 0r سم ثم • ب سم ثم 10 سم للحصول على اعلى محصول وجودة. 